\title{
Divergence history of the Rufous-tailed Tailorbird (Orthotomus sericeus) of Sundaland: Implications for the biogeography of Palawan and the taxonomy of island species in general
}

\author{
Author(s): Haw Chuan Lim, Vivien L. Chua, Phred M. Benham, Carl H. Oliveros, Mustafa Abdul
}

Rahman, Robert G. Moyle, and Frederick H. Sheldon

Source: The Auk, 131(4):629-642.

Published By: The American Ornithologists' Union

DOI: http://dx.doi.org/10.1642/AUK-14-80.1

URL: http://www.bioone.org/doi/full/10.1642/AUK-14-80.1

BioOne (www.bioone.org) is a nonprofit, online aggregation of core research in the biological, ecological, and environmental sciences. BioOne provides a sustainable online platform for over 170 journals and books published by nonprofit societies, associations, museums, institutions, and presses.

Your use of this PDF, the BioOne Web site, and all posted and associated content indicates your acceptance of BioOne's Terms of Use, available at www.bioone.org/page/terms of use.

Usage of BioOne content is strictly limited to personal, educational, and non-commercial use. Commercial inquiries or rights and permissions requests should be directed to the individual publisher as copyright holder. 


\title{
Divergence history of the Rufous-tailed Tailorbird (Orthotomus sericeus) of Sundaland: Implications for the biogeography of Palawan and the taxonomy of island species in general
}

\author{
Haw Chuan Lim, ${ }^{1, a}$ Vivien L. Chua, ${ }^{1}$ Phred M. Benham, ${ }^{1, b}$ Carl H. Oliveros, ${ }^{2}$ Mustafa Abdul Rahman, ${ }^{3}$ Robert \\ G. Moyle, ${ }^{2}$ and Frederick H. Sheldon ${ }^{1 *}$ \\ ${ }^{1}$ Museum of Natural Science and Department of Biological Sciences, Louisiana State University, Baton Rouge, Louisiana, USA \\ 2 Biodiversity Institute and Department of Ecology and Evolutionary Biology, University of Kansas, Lawrence, Kansas, USA \\ ${ }^{3}$ Faculty of Resource Science and Technology, Universiti Malaysia Sarawak, Kota Samarahan, Sarawak, Malaysia \\ ${ }^{a}$ Current address: Smithsonian Institution, National Museum of Natural History, Washington, District of Columbia, USA \\ ${ }^{b}$ Current address: Department of Animal Biology, University of Illinois, Urbana, Illinois, USA \\ * Corresponding author: fsheld@Isu.edu
}

Submitted April 13, 2014; Accepted June 6, 2014; Published August 27, 2014

\begin{abstract}
The Rufous-tailed Tailorbird (Orthotomus sericeus)—a Sunda endemic - is divided into 3 morphologically based subspecies: one in western Sundaland (Malay Peninsula, Sumatra, and associated islands), one from the Natuna Islands in the South China Sea, and one on Borneo, Palawan, and smaller islands of the Sunda continental shelf east of Borneo. Previous study, however, suggested that these subspecies do not conform to molecular genetic subdivisions of the species. We reexamined the morphology and performed molecular phylogeographic and multi-locus coalescent analysis of two subspecies of Rufous-tailed Tailorbird comprising populations on the Malay Peninsula, Sumatra, Borneo, and Palawan. We found (1) little morphological difference among the two subspecies, (2) no substantial genetic differences between the Borneo and western Sunda populations, but (3) marked genetic divergence between the Palawan and other populations. We conclude that the Bornean and western Sunda populations interbred extensively during Quaternary glacio-eustatic land connections, whereas the Bornean and Palawan populations did not. Unlike the other Greater Sunda Islands, Palawan has not been attached by a land bridge to the rest of Sundaland for at least one million years, and its relative isolation has prevented extensive intermixing between Palawan's and other Sunda populations. Thus, the Palawan population appears to be on its own evolutionary trajectory. The ability to demonstrate extensive interbreeding among some Sunda island populations, but not others, illustrates the practicality of testing Gill's (2014) "null hypothesis" that morphologically distinct populations on different islands are different species unless a compelling argument can be made to the contrary. In this case, Rufous-tailed Tailorbird morphology provided little or misleading evidence of the extent of interbreeding, whereas modern genetic analysis provided a clear view.
\end{abstract}

Keywords: Borneo, coalescent analysis, glacial cycles, multi-locus analysis, phylogeography, species concepts

Historia de divergencia de Orthotomus sericeus de Sondalandia: Implicancias para la biogeografía de Palawan y la taxonomía de las especies de las islas en general

\section{RESUMEN}

Orthotomus sericeus_-endémica de Sonda_está dividida en tres subespecies en base a la morfología: una del oeste de Sondalandia (Península Malay, Sumatra e islas asociadas), una de las Islas Natuna en el Mar del Sur de China y una en Borneo, Palawan e islas más pequeñas de la plataforma continental de Sonda al este de Borneo. Estudios previos, sin embargo, sugirieron que estas subespecies no coinciden con las subdivisiones genéticas moleculares de la especie. Reexaminamos la morfología y realizamos análisis moleculares filogeográficos y de coalescencia multi-locus de dos subespecies de $O$. sericeus abarcando poblaciones de la Península Malay, Sumatra, Borneo y Palawan. Encontramos (1) poca diferencia morfológica entre las dos subespecies, (2) falta de diferencias genéticas substanciales entre las poblaciones de Borneo y del oeste de Sonda, pero (3) divergencia genética marcada entre la población de Palawan y otras poblaciones. Concluimos que las poblaciones de Borneo y del oeste de Sonda se entrecruzaron enormemente durante las conexiones terrestres glacio-eustáticas del Cuaternario, mientras que las poblaciones de Borneo y de Palawan no lo hicieron. A diferencia de las otras Islas Mayores de Sonda, Palawan no ha estado unida por un puente terrestre al resto de Sondalandia por al menos un millón de años, y su aislamiento relativo ha impedido una gran entremezcla entre las poblaciones de Palawan y otras poblaciones de Sonda. Así, la población de Palawan parece estar en su propia trayectoria evolutiva. La posibilidad de demostrar un enorme entrecruzamiento entre algunas 
poblaciones de las islas de Sonda, pero no entre otras, ilustra la practicidad de evaluar la "hipótesis nula" de Gill (2014) de que poblaciones morfológicamente distintivas en islas diferentes son especies diferentes, a menos de que haya un argumento de peso en contra. En este caso, la morfología de O. sericeus brindó evidencia limitada o confusa del grado de entrecruzamiento, mientras que los análisis genéticos modernos brindaron un panorama claro.

Palabras clave: análisis de coalescencia, análisis multi-locus, Borneo, ciclos glaciares, conceptos de especie, filogeografía

\section{INTRODUCTION}

Palawan is a large Philippine island $\left(14,650 \mathrm{~km}^{2}\right)$ connected to the northeastern end of Sundaland (Figure 1), the biogeographic region of Southeast Asia that encompasses the Sunda continental shelf and its constituent land masses: the Malay Peninsula, Sumatra, Java, Bali, Borneo, Palawan, and many other islands of the IndoMalayan Archipelago (Whitmore 1981, 1987). During the Pliocene and Pleistocene, the Sunda shelf was exposed as land numerous times by glacial-eustatic sea level lowering, periodically uniting the Sunda islands with each other and the Asian mainland (Voris 2000, Sathiamurthy and Voris 2006). At these times, Palawan formed a peninsula northeast of Borneo pointing into the heart of the oceanic Philippine islands. Thus, biogeographers traditionally assumed Palawan was the main conduit for Asian vertebrates to reach the Philippines (Dickerson et al. 1928, Delacour and Mayr 1946, Inger 1954, Darlington 1957, Diamond and Gilpin 1983, Heaney 1985, Dickinson 1991). They also assumed that Asian invasions of the oceanic Philippines occurred relatively recently, i.e. during the late Quaternary, when glacial events were most frequent and dramatic. We now know, however, that invasions of the Philippines by many Asian forest animals occurred much earlier than the late Pleistocene, and the route through Palawan was less important than previously believed (e.g., for birds: Lim et al. 2010, Oliveros and Moyle 2010, Sheldon et al. 2012, Gamauf and Haring 2004, Moyle et al. 2007, Jones and Kennedy 2008, Moyle et al. 2009, Sheldon et al. 2009). The Sunda shelf, when exposed as land, does not simply transform into a wide expanse of rainforest through which forest animals can easily travel, but rather it seems to become a matrix of diverse habitats and montane and river barriers (Brandon-Jones 1998, Gathorne-Hardy et al. 2002, Meijaard and van der Zon 2003, Gorog et al. 2004, Cannon et al. 2009, Wurster et al. 2010, Slik et al. 2011). Movement though Palawan is further impeded by water barriers at both ends, making it act more as a filter or cul-de-sac than a transmigration facilitator (Esselstyn et al. 2010).

Part of the reason Palawan has been misunderstood as a biogeographic force is because only recently have we begun to understand the degree to which it is not a typical Sunda island. Whereas elements of Borneo, Sumatra, and even Java have been part of the Sunda continental core since the Cretaceous (Hall 2002, 2009), Palawan is a newcomer to the area. It began as a continental fragment that broke off southern China $\sim 30 \mathrm{Ma}$ and drifted south to hit the Sunda shelf near northeastern Borneo 20-10 Ma (Hall 1998, Zamoros and Matsuoka 2004, Yumul et al. 2009). Although Palawan was originally thought to have been submerged during all or most of its southward journey, Blackburn et al. (2010) and Siler et al. (2012) have argued that little evidence of complete submergence has been presented. Instead, on the basis of molecular genetic comparisons of frogs and lizards and a review of geology, they have suggested that parts of Palawan may actually have remained emergent during the entire journey. Moreover, the micro-continental plate on which Palawan sits would have drifted south with other micro-plates that later played a role in the accretion of some of the oceanic Philippine islands (e.g., Panay, Carabao, Mindoro, and the Romblons). Thus, Palawan may have acted as an "ark," transporting vertebrates and other organisms to the oceanic Philippines, as well as to Sundaland and even Sulawesi (Blackburn et al. 2010). When Palawan reached its current location, it was thrust upward and took on its present conformation (Durkee 1993, Hall 2002, Yumul et al. 2009). As a result of its voyage, Palawan experienced a much different history than the other Sunda islands. Also, recent evidence indicates that Palawan has not been "firmly" connected to Sundaland as a result of sea level lowering. Although sea level models originally suggested a land connection between greater Borneo and Palawan during the last glacial maximum (e.g., Rohling et al. 1998), recent work indicates that during the most extreme glacial events of the last $700 \mathrm{Ka}$, sea levels did not fall below 125 m ( $\pm 12 \mathrm{~m})$; before $700 \mathrm{Ka}$, sea level drops were even less extreme (Bintanja et al. 2005). Because Palawan is separated from Borneo by a $140 \mathrm{~m}$ channel (Heaney 1986), it has probably been isolated by a narrow water barrier for much of the Quaternary, if not forever (Bintanja et al. 2005, Esselstyn et al. 2010). Even if the channel were completely closed, the coastal habitat spanning Borneo and Palawan (e.g., mangrove, swamp forest, coastal strand) may not have been hospitable to most species of the interior lowland rainforest.

Palawan's relatively recent and tenuous connection to Sundaland helps explain the history of its forest avifauna. Most of its upland birds appear to have colonized from Sundaland within the last 5-8 Ma; fewer have colonized 


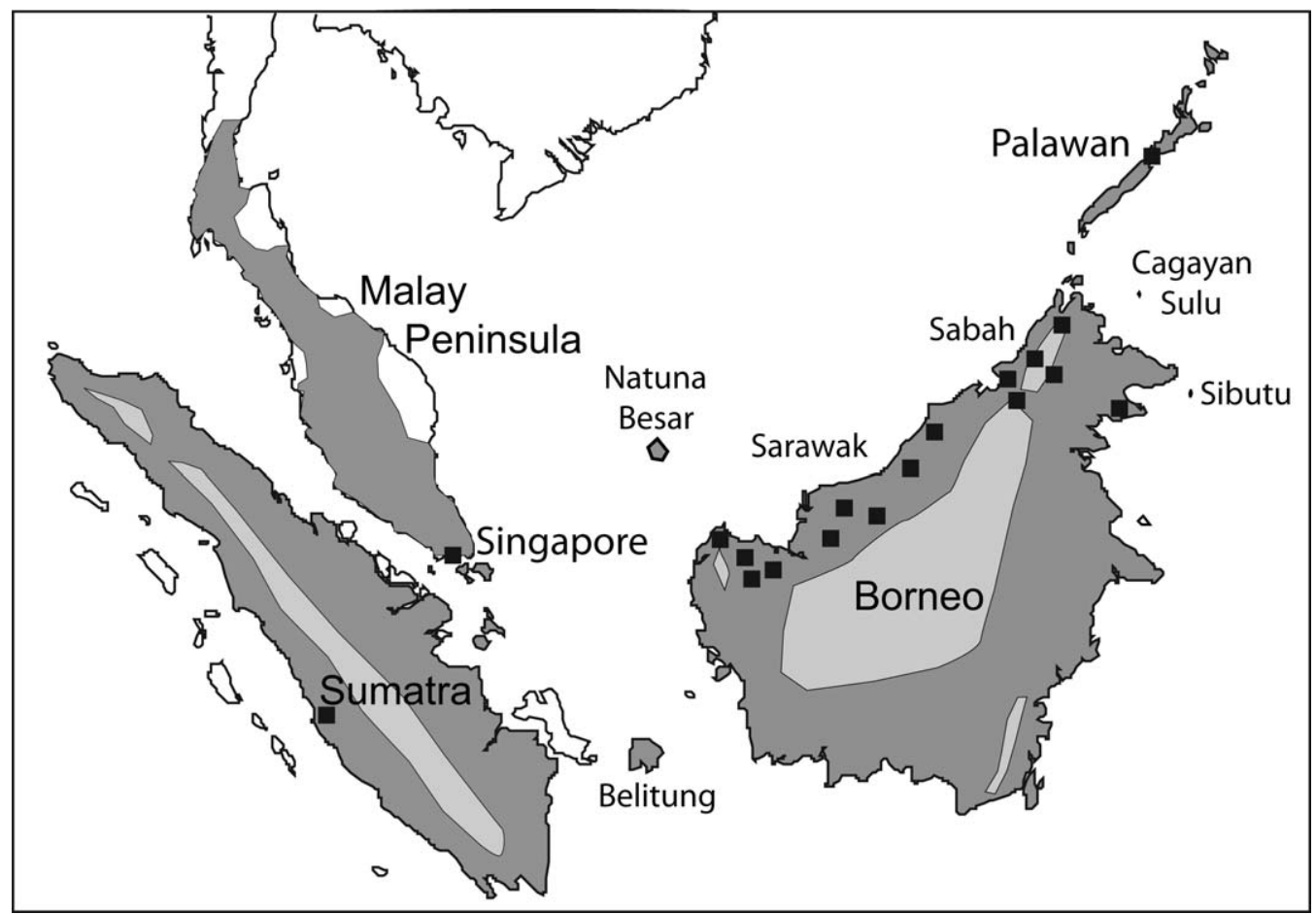

FIGURE 1. Map of Rufous-tailed Tailorbird distribution and sampling sites (black squares). Dark gray indicates the approximate distribution of the species (Sundaic lowlands). It is absent from light gray areas (mountains) and blank areas (Van Marle and Voous 1988, Madge 2006, Wells 2007, Phillipps and Phillipps 2014).

from the oceanic Philippines; none seems old enough to have ridden the island as an ark from mainland Asia (Lim et al. 2010, Lohman et al. 2010, Oliveros and Moyle 2010, Rahman et al. 2010, Oliveros et al. 2012, Irestedt et al. 2013). Among its Sunda colonizers, there appear to be 2 classes of genetic divergence (Table 1): the first representing earlier colonists, each of which is morphologically and genetically distinct from its sister taxon in Sundaland; and the second comprising more recent colonists displaying little morphological or genetic difference from their

TABLE 1. Bornean and Palawan sister taxa and their uncorrected proportional mitochondrial divergence values (Lim et al. 2010, Lohman et al. 2010, Oliveros and Moyle 2010, Rahman et al. 2010, Sheldon et al. 2012, R.G.M. and C.H.O. personal observation).

\begin{tabular}{|c|c|c|c|c|}
\hline Palawan taxon ${ }^{1}$ & Bornean taxon ${ }^{1}$ & Main feeding guild & Main forest habitat & Divergence value \\
\hline \multicolumn{5}{|l|}{$\begin{array}{c}\text { Class 1: Higher morphological } \\
\text { and molecular divergence }\end{array}$} \\
\hline lole palawanensis & I. olivacea & frugivore & $1^{\circ} \& 2^{\circ}$ & ND2 17\% \\
\hline Malacopteron palawanense & M. magnirostre & insectivore & $1^{\circ}$ & ND2 14\% \\
\hline Pycnonotus cinereifrons & P. simplex & frugivore & $2^{\circ}$ & ND2 14\% \\
\hline Ptilocichla falcata & P. leucogrammica & insectivore & $1^{\circ}$ & ND2 13.5\% \\
\hline Malacocincla cinereiceps & M. malaccensis & insectivore & $1^{\circ}$ & ND2 12.6\% \\
\hline Alophoixus frater & A. bres & frugivore & $1^{\circ}$ & ND2 12\% \\
\hline Arachnothera dilutior & A. longirostra & nectarivore & $1^{\circ} \& 2^{\circ}$ & Cytb 9\% \\
\hline Copsychus niger & C. stricklandii & insectivore & $1^{\circ}$ & ND2 9\% \\
\hline Pachycephala cinerea plateni & P. c. cinerea & insectivore & $1^{\circ} \& 2^{\circ}$ & ND2 8.5\% \\
\hline Macronus gularis & M. bornensis & insectivore & $2^{\circ}$ & ND2 $7.9 \%$ \\
\hline \multicolumn{5}{|l|}{$\begin{array}{l}\text { Class 2: Lower morphological } \\
\text { and molecular divergence }\end{array}$} \\
\hline Orthotomus sericeus & O. sericeus & insectivore & $2^{\circ}$ & ND2 1.9\% \\
\hline Pycnonotus atriceps & P. atriceps & frugivore & $2^{\circ}$ & ND2 $0.9 \%$ \\
\hline Alcedo meninting & A. meninting & piscivore & $1^{\circ} \& 2^{\circ}$ & ND2 0.8\% \\
\hline Ceyx erithaca & C. erithaca & insectivore & $1^{\circ} \& 2^{\circ}$ & ND2 0.3\% \\
\hline
\end{tabular}

${ }^{1}$ Classification of Gill and Donsker (2014). 
Bornean sisters. The first group consists entirely of Palawan endemics, many of which have been recently accorded status as full species. Among these endemics are the sister species of some Sunda taxa that are completely or mainly restricted to mature forest in Borneo, e.g., Bornean Wren-Babbler (Ptilocichla leucogrammica), Short-tailed Babbler (Malacocincla malaccensis), and Grey-cheeked Bulbul (Alophoixus bres). Such species would be incapable of dispersing from Borneo to Palawan without a substantial rainforest corridor connecting the 2 islands (assuming ancestors of these species had the same habitat requirements as the modern birds). The second group of Palawan taxa, i.e. those displaying little divergence from their Bornean sisters, includes species that are expected to be good overwater dispersers: e.g., 2 kingfishers that occur in mangrove-Oriental Dwarf Kingfisher (Ceyx erithaca) and Blue-eared Kingfisher (Alcedo meninting) - and the highly vagile Black-headed Bulbul (Pycnonotus atriceps). One species that exhibits little morphological and only moderate genetic distinctiveness between its Palawan and Bornean populations is the Rufous-tailed Tailorbird (Orthotomus sericeus). Unlike the kingfishers and Black-headed Bulbul, the tailorbird is a notably poor flier and, presumably, disperser. Thus, it would not be expected to move back and forth between Borneo and Palawan without a land bridge.

The Rufous-tailed Tailorbird occurs on the Malay Peninsula, Sumatra, Belitung, Borneo, Palawan, Natunas, and various coastal islands (Figure 1). In the Philippines it is found only on islands that lie on the Sunda continental shelf, i.e. the Palawan chain (Balabac, Palawan, Busuanga, Culion), the western Sulu Archipelago (Sibutu, Sitanki, Omapoy, Sipangkot, Tumindao), and Cagayan Sulu (Dickinson et al. 1991). Originally, 4 subspecies of Rufous-tailed Tailorbird were described: the nominate O. s. sericeus of Borneo, O. s. nuntius of Cagayan Sulu Island and the Sulu Archipelago (Bangs 1922), O. s. hesperius of Sumatra, Belitung, and the Malay peninsula (Chasen and Kloss 1931), and O. s. rubicundulus of the Natuna Islands (Oberholser 1932). Individuals from Palawan were not examined in this initial taxonomic process. Later, the Palawan and other western Philippine populations were merged into O. s. sericeus because they were considered undifferentiated from Bornean birds (Peters 1939, Parkes 1960, Dickinson et al. 1991). This arrangement left just 3 morphologically based subspecies: O. s. hesperius, O. s. sericeus, and O. s. rubicundulus. However, subsequent molecular comparisons suggest this arrangement may be wrong. Mitochondrial ND2 sequence comparisons have indicated that the Palawan population is $\sim 1.9 \%$ divergent from the Bornean population (Sheldon et al. 2012) and that the Borneo and western Sunda populations have recently and extensively intermixed (Lim et al. 2011).
In this paper, we explore Rufous-tailed Tailorbird phylogeography further in an effort to improve our understanding of the species' population history and the historical relationship between Palawan and the rest of Sundaland. Our investigation proceeds in 2 steps. First, we reexamine previous findings based on morphological characteristics and ND2 sequence divergence by comparing a relatively large number of individuals from populations spanning Sundaland. This step shows that populations from western Sundaland (Sumatra and the Malay Peninsula), Borneo, and Palawan are very similar to one another morphologically, and confirms that the Palawan population is genetically distinct from the western Sunda and Borneo populations. Next, we examine the divergence history of the Palawan population relative to the combined western Sunda and Borneo populations using a multi-locus coalescent analysis of ND2 and nuclear gene sequences. Specifically, we use immigration with migration analysis (IMa) to estimate the time since divergence of the 2 populations, levels of gene flow between them since their divergence, and their effective population sizes. This analysis provides a fairly clear picture of the recent biogeographic history of Rufoustailed Tailorbird populations. It also illustrates an effective approach to identifying species limits in an island setting and, as such, illustrates the practicality of testing Gill's (2014) "null hypothesis" that morphologically distinguishable populations on different islands be considered different species unless a compelling argument can be made to the contrary.

\section{METHODS}

Because original descriptions of Rufous-tailed Tailorbird subspecies were vague and confused (Oberholser 1932, Peters 1939, Parkes 1960), we reassessed morphological variation among the populations whose DNA was compared in this study using specimens borrowed from the Academy of Natural Sciences of Drexel University, American Museum of Natural History, Delaware Museum of Natural History, Field Museum, Louisiana State University Museum of Natural Science, National Museum of Natural History (U.S.A), Natural History Museum (U.K.), University of Kansas Museum of Natural History, and the Western Foundation. The taxa compared were $O$. s. sericeus from Borneo (30 individuals), O. s. hesperius from western Sundaland (peninsular Malaysia, Singapore, and Sumatra; 31 individuals), and O. s. sericeus from Palawan (31 individuals). We did not compare the Natuna and Cagayan Sulu populations because very few specimens exist from these sites; almost all are types (Bangs 1922, Chasen and Kloss 1931, Oberholser 1932), which are difficult to borrow and which museums are loath to subsample for DNA; and all are very old (collected in 1893, 
1900, and 1921) and, thus, likely to be faded. Also, we reasoned that the populations of Natuna, which lies in the South China Sea between Borneo and the Malay Peninsula (Figure 1), would have been well connected and likely to interbreed with western populations during most or all glacial events (Voris 2000, Cannon et al. 2009). Cagayan Sulu is biogeographically more interesting than the Natunas, as it lies at the eastern limit of Sundaland. Unfortunately, only one specimen is available from this island, the type for the original O. nuntius (Bangs 1922). We hope to work with this specimen in the future.

We examined plumage color and measured 7 characters (all measurements were taken by VLC from adult birds using standard calipers): culmen length, length from nostril to bill tip, bill width, and bill depth; wing length; tail length; and tarsus length. Measurement data were analyzed using principal components analysis (PCA) and discriminant function analysis (DFA) using program "R" (R Development Core Team 2008) with the package MASS (Venables and Ripley 2002). PCA was based on a singular value decomposition of the data matrix for numerical accuracy. To test for sex-specific differences, separate analyses were performed on male and female specimens.

For molecular comparisons, we obtained mitochondrial ND2 (nicotinamide adenine dinucleotide dehydrogenase subunit 2) sequences of Rufous-tailed Tailorbird from 51 individuals from 3 areas (Table 2): Palawan (3 individuals); Malaysian Borneo (44 individuals); and Sumatra and Singapore (4 individuals). Two outgroup species were used in the phylogenetic analyses: Grey-backed Tailorbird $(O$. derbianus) of the Philippines and Ashy Tailorbird (O. ruficeps) from Borneo. These species are members of the clades closest to Rufous-tailed Tailorbird, but are still 9$11 \%$ divergent from it (Sheldon et al. 2012). ND2 sequences of 21 specimens, including outgroups, were produced in previous studies (Nguembock et al. 2007, Lim and Sheldon 2011, Sheldon et al. 2012); their GenBank numbers are listed in Table 2. Seven nuclear loci were sequenced in 19 individuals (Table 2). Six of the nuclear loci were autosomal: 16214 (methylmalonic aciduria type A protein mitochondrial precursor), 20771 (p21-activated protein kinase-interacting protein), and 27189 (gammatubulin complex component 3) from Backström et al. (2008a, 2008b); GARS (glythyl-tRNA synthetase intron 11) from Kimball et al. (2009); and GADPH (glyceraldehyde 3$\mathrm{PDH}$ ) and TGFB (fifth nuclear intron of transforming growth factor, $\beta 2$ ) from Primmer et al. (2002). One was a Z-linked locus: BRM15 (a core ATPase of the SWI/SNF ATP-dependent chromatin remodeling complex) from Borge et al. (2005).

DNA was extracted from ethanol-preserved pectoral muscle using DNeasy tissue kits (QIAGEN, Hilden, Germany) or from blood preserved in Queen's Lysis Buffer (Seutin et al. 1991) using a standard phenol-chloroform protocol. PCR was conducted using primers published in the citations above. PCR products were purified with $20 \%$ polyethylene glycol and cycle-sequenced in both directions using PCR primers and BigDye Terminator Cycle-Sequencing kits version 3.1 (Applied Biosystems, Foster City, California, USA). Cycle-sequencing products were cleaned with Sephadex G-50 fine (GEHealthcare, Little Chalfont, Buckinghamshire, UK) before analysis on an ABI Prism 3100 Genetic Analyzer (Applied Biosystems). The sequences were assembled and edited in Sequencher version 4.7 (Gene Codes, Ann Arbor, Michigan, USA). To determinate allelic phases of non-recombining blocks in nuclear sequences, we used TA-cloning and computational procedures described in Lim and Sheldon (2011). GenBank numbers of sequences produced in this study are KJ864966-KJ865225.

The phylogeny of Rufous-tailed Tailorbird populations was estimated from aligned ND2 sequences using maximum-likelihood and Bayesian approaches, with models of molecular evolution first estimated with jmodeltest 0.1.1 (Posada 2008). We used MrBayes 3.2 to construct a majority rule consensus Bayesian tree using the following parameters: 2 simultaneous runs, number of MCMC generations $=10$ million (sampling every 1,000 trees), burn-in fraction $=0.25,4$ search chains in each run, general time reversible model of nucleotide substitution (nst $=6)$, and gamma-distributed rate variation across sites (Ronquist et al. 2012). We ascertained that runs in MrBayes had converged in view of the small average standard deviation of split frequencies (0.004) and by inspection of log-likelihood-value and parameter trend lines in the program Tracer v1.6. For maximum likelihood phylogenetic analysis, 500 bootstrap replicates were estimated using a genetic algorithm implemented by the GARLI web service: http://www.molecularevolution.org/ software/phylogenetics/garli/garli_create_job (Zwickl 2006). GARLI parameters were set as follows: nonpartitioned analysis; general time reversible model of nucleotide substitution; estimated base frequencies and proportion of invariant sites; and gamma-shaped, acrosssite rate heterogeneity (4 categories).

We evaluated Rufous-tailed Tailorbird population structure using an analysis of molecular variance (AMOVA) of the ND2 data in ARLEQUIN 3.5 (Excoffier and Lischer 2010). Following results from phylogenetic analysis (see Results) and based on our previous observation of genetic variation ( $\mathrm{Lim}$ et al. 2011), we partitioned the data by grouping birds from western Sundaland and Borneo into one population (BWS) and birds from Palawan into another. We also constructed a median joining network from the ND2 data using the program Network v.4.6 (Bandelt et al. 1999) to visualize genetic diversity and geographical relationships. 
TABLE 2. Orthotomus species and DNA samples used in this study.

\begin{tabular}{|c|c|c|c|c|c|c|c|c|c|}
\hline Species ${ }^{1}$ & Subspecies & Country & $\begin{array}{c}\text { State } \\
\text { or Province }\end{array}$ & $\begin{array}{l}\text { Collection } \\
\text { locality }\end{array}$ & Lat. & Long. & $\begin{array}{l}\text { Specimen } \\
\text { number }^{2}\end{array}$ & $\begin{array}{c}\text { ND2 } \\
\text { from previous } \\
\text { studies }^{3}\end{array}$ & $\begin{array}{c}\text { Nuclear } \\
\text { genes } \\
\text { sequenced }\end{array}$ \\
\hline O. sericeus & sericeus & Philippines & Palawan & Puerto Princesa & 9.97 & 118.78 & KUNHM 12601 & & yes \\
\hline O. sericeus & sericeus & Philippines & Palawan & Puerto Princesa & 9.97 & 118.78 & KUNMH 12624 & & yes \\
\hline O. sericeus & sericeus & Philippines & Palawan & Puerto Princesa & 9.97 & 118.78 & KUNMH 12631 & JX006141* & yes \\
\hline O. sericeus & sericeus & Malaysia & Sabah & Tawau Hills & 4.4 & 117.89 & LSU B51050 & & \\
\hline O. sericeus & sericeus & Malaysia & Sabah & Tawau Hills & 4.4 & 117.89 & LSU B51057 & & \\
\hline O. sericeus & sericeus & Malaysia & Sabah & Serinsim & 6.29 & 116.71 & LSU B46975 & & \\
\hline O. sericeus & sericeus & Malaysia & Sabah & Serinsim & 6.29 & 116.71 & LSU B46989 & HQ011047* & yes \\
\hline O. sericeus & sericeus & Malaysia & Sabah & Serinsim & 6.29 & 116.71 & LSU B46990 & & \\
\hline O. sericeus & sericeus & Malaysia & Sabah & Serinsim & 6.29 & 116.71 & LSU B47010 & HQ011048* & \\
\hline O. sericeus & sericeus & Malaysia & Sabah & Serinsim & 6.29 & 116.71 & LSU B47020 & & \\
\hline O. sericeus & sericeus & Malaysia & Sabah & Ulu Kimanis & 5.5 & 116 & KUNHM 17792 & JN826602* & yes \\
\hline O. sericeus & sericeus & Malaysia & Sabah & Crocker Range & 5.4 & 116.1 & LSU B36342 & HQ011046* & yes \\
\hline O. sericeus & sericeus & Malaysia & Sabah & Crocker Range & 5.4 & 116.1 & LSU B36357 & & \\
\hline O. sericeus & sericeus & Malaysia & Sabah & Crocker Range & 5.4 & 116.1 & LSU B36370 & & \\
\hline O. sericeus & sericeus & Malaysia & Sabah & Klias & 5.33 & 115.67 & LSU B47190 & & \\
\hline O. sericeus & sericeus & Malaysia & Sabah & Klias & 5.33 & 115.67 & LSU B47191 & HQ011049* & yes \\
\hline O. sericeus & sericeus & Malaysia & Sabah & Mendolong & 4.85 & 115.7 & LSU B51012 & HQ011050* & yes \\
\hline O. sericeus & sericeus & Malaysia & Sabah & Mendolong & 4.85 & 115.7 & LSU B51034 & & \\
\hline O. sericeus & sericeus & Malaysia & Sarawak & Miri-Bintulu & 4.16 & 114.03 & LSU B58177 & & \\
\hline O. sericeus & sericeus & Malaysia & Sarawak & Niah town & 3.74 & 113.79 & LSU B58183 & & \\
\hline O. sericeus & sericeus & Malaysia & Sarawak & Batu Niah & 3.82 & 113.76 & LSU B58160 & & yes \\
\hline O. sericeus & sericeus & Malaysia & Sarawak & Tatau Town & 2.89 & 112.87 & LSU B58190 & & yes \\
\hline O. sericeus & sericeus & Malaysia & Sarawak & Tatau Town & 2.89 & 112.87 & LSU B58191 & & \\
\hline O. sericeus & sericeus & Malaysia & Sarawak & Kanowit & 2.08 & 112.14 & LSU B52213 & & \\
\hline O. sericeus & sericeus & Malaysia & Sarawak & Kanowit & 2.08 & 112.14 & LSU B52214 & & \\
\hline O. sericeus & sericeus & Malaysia & Sarawak & Mukah & 2.92 & 112.15 & LSU B52224 & & \\
\hline O. sericeus & sericeus & Malaysia & Sarawak & Mukah & 2.92 & 112.15 & LSU B52226 & & \\
\hline O. sericeus & sericeus & Malaysia & Sarawak & Mukah & 2.92 & 112.15 & LSU B52227 & & \\
\hline O. sericeus & sericeus & Malaysia & Sarawak & Sibu & 2.36 & 111.82 & LSU B58208 & & \\
\hline O. sericeus & sericeus & Malaysia & Sarawak & Bako & 1.72 & 110.48 & BMNHC 82057 & & \\
\hline O. sericeus & sericeus & Malaysia & Sarawak & Bako & 1.72 & 110.48 & BMNHC 82075 & & \\
\hline O. sericeus & sericeus & Malaysia & Sarawak & Bako & 1.72 & 110.48 & BMNHC 82078 & & \\
\hline O. sericeus & sericeus & Malaysia & Sarawak & Bako & 1.72 & 110.48 & BMNHC 81920 & & \\
\hline O. sericeus & sericeus & Malaysia & Sarawak & Kota Samarahan & 1.46 & 110.45 & LSU B58212 & HQ011055* & yes \\
\hline O. sericeus & sericeus & Malaysia & Sarawak & Kota Samarahan & 1.46 & 110.45 & LSU B58216 & HQ011056* & \\
\hline O. sericeus & sericeus & Malaysia & Sarawak & Kota Samarahan & 1.46 & 110.45 & LSU B58217 & HQ011057* & \\
\hline O. sericeus & sericeus & Malaysia & Sarawak & Kubah & 1.65 & 110.22 & BMNHC 82014 & & \\
\hline O. sericeus & sericeus & Malaysia & Sarawak & Kubah & 1.65 & 110.22 & BMNHC 82027 & & \\
\hline O. sericeus & sericeus & Malaysia & Sarawak & Padawan & 1.18 & 110.2 & LSU B52139 & & \\
\hline O. sericeus & sericeus & Malaysia & Sarawak & Padawan & 1.18 & 110.2 & LSU B52144 & HQ011052* & \\
\hline O. sericeus & sericeus & Malaysia & Sarawak & Padawan & 1.18 & 110.2 & LSU B52145 & & \\
\hline O. sericeus & sericeus & Malaysia & Sarawak & Padawan & 1.18 & 110.2 & LSU B52136 & & \\
\hline O. sericeus & sericeus & Malaysia & Sarawak & Padawan & 1.18 & 110.2 & LSU B52137 & HQ011051* & yes \\
\hline O. sericeus & sericeus & Malaysia & Sarawak & Padawan & 1.18 & 110.2 & LSU B52147 & & \\
\hline O. sericeus & sericeus & Malaysia & Sarawak & Matang & 1.61 & 110.2 & LSU 52153 & HQ011053* & yes \\
\hline O. sericeus & sericeus & Malaysia & Sarawak & Matang & 1.61 & 110.2 & LSU B52167 & HQ011054* & \\
\hline O. sericeus & hesperius & Singapore & Singapore & Pulau Ubin & 1.41 & 103.96 & $J 1165$ & HQ011060* & yes \\
\hline O. sericeus & hesperius & Malaysia & Singapore & Pulau Ubin & 1.41 & 103.96 & J1167 & HQ011061* & yes \\
\hline O. sericeus & hesperius & Singapore & Singapore & Bukit Batok & 1.35 & 103.75 & BMNHC 81966 & HQ011058* & yes \\
\hline O. sericeus & hesperius & Singapore & Singapore & Marina South & 1.27 & 103.85 & BMNHC 81969 & HQ011059* & yes \\
\hline O. sericeus & hesperius & Indonesia & Sumatra & Lunang Town & -2.27 & 101.03 & BMNHC 67468 & HQ011062* & yes \\
\hline O. derbianus* & & Philippines & Catanduanes & Catanduanes Is. & 13.7 & 124.33 & FMNH 350975 & $J X 006122^{* *}$ & \\
\hline O. ruficeps* & & Malaysia & Sabah & Klias & 5.33 & 115.67 & LSU B47143 & JX006132* & \\
\hline
\end{tabular}

${ }^{1}$ Classification follows Gill and Donsker (2014). * indicates outgroups.

${ }^{2} \mathrm{BMNHC}=$ Burke Museum of Natural History and Culture, FMNH $=$ Field Museum of Natural History, KUMNH $=$ University of Kansas Natural History Museum, LSU = Louisiana State Museum of Natural Science.

${ }^{3}$ GenBank numbers for ND2 sequences obtained from previous studies: *Lim et al. (2011) and Sheldon et al. (2012); and **Nguembock et al. (2007).

4 "Yes" indicates that nuclear loci were sequenced in this study. Seven loci were sequenced for most individuals; however, KUNHM 12601 lacks GAPDH and 16214; KUNHM 12631 lacks GARS, 16214 and 20771; LSU B58160 lacks BRM15 and 16214; KUNHM 17792 lacks 20771. 


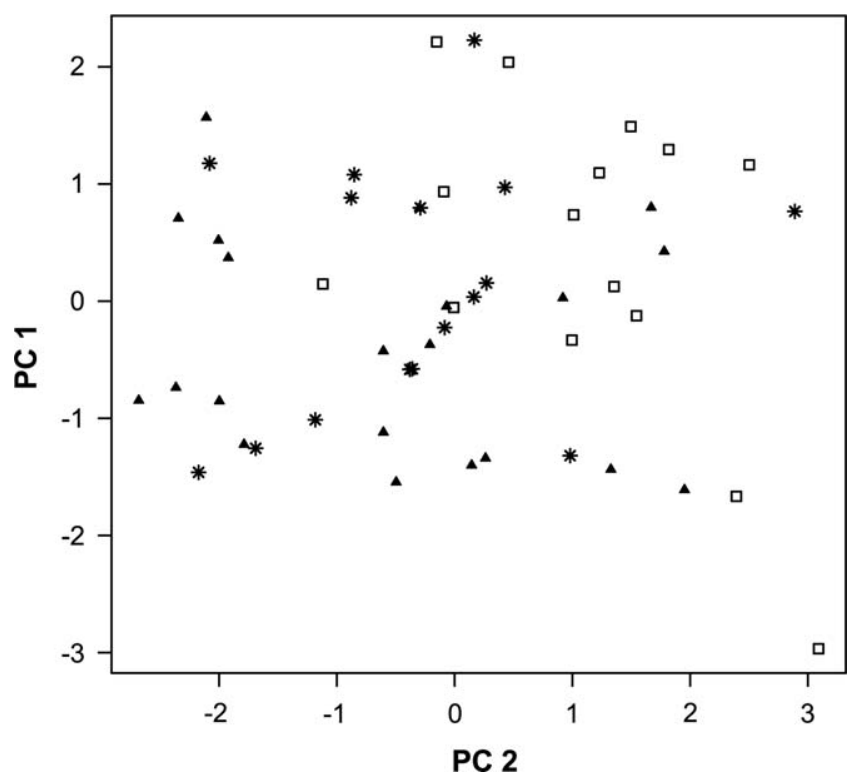

FIGURE 2. PCA of 6 size characters of male Rufous-tailed Tailorbird. Open squares: Borneo; closed triangles: western Sundaland; and stars: Palawan.

IMa analysis (Hey and Nielsen 2004) was conducted to determine time of divergence, effective population sizes, and gene flow between Palawan and BWS. In this analysis, we used phased sequences of all 7 nuclear genes and sequences of ND2. Approximate mutation rates of 4 nuclear genes (BRM15, GAPDH, GARS, and TGFB) and ND2 were applied so that IMa would produce results in demographic units (Lim and Sheldon 2011). To determine prior limits and run convergence characteristics, we performed several short-length (5 million generation) and moderate-length (50 million generation) IMa runs. We then carried out a final analysis of 100 million generations with 10 heated chains (total run time $=343 \mathrm{~h}$; geometric heating scheme, $g_{1}=0.8, g_{2}=0.9$ ). We recorded results every 100 generations and discarded the first $10 \%$ as burn-in. We set one year as the generation time, as a best guess, but note that little is known about the breeding cycle of Rufous-tailed Tailorbird (Van Marle and Voous 1988, Smythies 1999, Wells 2007). In addition to using IMa to produce estimates of demographic parameters and divergence, we also used it to assess the fit of simpler demographic models nested within the full six-parameter divergence model (Hey and Nielsen 2007). In these nested models $(n=16)$, simplifications included assuming populations have the same effective size and symmetrical gene flow. We assessed the fit of reduced models to the data by comparing them against their null models using likelihood ratio tests (LRT). The significance of the differences was then determined with appropriate chi-squared distributions and Bonferroni correction for multiple comparisons.

\section{RESULTS}

We observed no consistent differences in plumage among the 92 specimens compared, but note that the specimens from Western Sundaland were old and potentially faded. PCA of combined male and female measurements indicated the majority of variance (57\%) was distributed among 2 components: PC1 (40\%) and PC2 (17\%). Wing and tail lengths accounted for most of this variation. In males alone, $50 \%$ of the variance was distributed between PC1 (32\%) and PC2 (19\%). In females, 55\% was in PC1 (38\%) and PC2 (16\%). None of the PCA scatter plots indicated a clear difference among populations; the male plot shows the most difference (Figure 2). DFA of all individuals was highly influenced by bill depth and total culmen length, as was the DFA of males. In females, it was most influenced by bill width and wing length. In jacknife analysis of all individuals, DFA properly classified $57 \%$ of the Borneo population, $65 \%$ of the Palawan population, and $58 \%$ of the western Sundaland population. Overall classification accuracy was $60 \%$. For males alone, DFA properly classified $60 \%$ to Borneo, $69 \%$ to Palawan population, and $67 \%$ to western Sundaland, with overall accuracy of $65 \%$. For females, DFA accuracy was $73 \%$ for Borneo, $60 \%$ for Palawan, and $70 \%$ for western Sundaland, with overall accuracy of $55 \%$. In general, none of the morphological characters we examined could discriminate effectively among the 3 populations (western Sundaland, Borneo, and Palawan) or the 2 subspecies (sericeus and hesperius).

The ND2 data consisted of 1,038 sites. Among Rufoustailed Tailorbirds, 982 sites were invariable, 40 polymorphic, 8 unique, and 32 parsimony informative. The average uncorrected ND2 divergence between the Palawan and BWS populations was $1.7 \%$. There were 20 haplotypes, haplotype diversity was 0.933 , and nucleotide diversity was 0.00528 . The haplotype network (Figure 3 ) showed a series of Bornean locations radiating from western Sundaland, and Palawan was differentiated by 19 steps from all other populations. AMOVA (Table 3) indicated a high degree of genetic structure occurring among populations, 63\% (Borneo, Palawan, and Western Sundaland), and less within, 37\%. Phylogenetic analysis of ND2 sequences using maximum likelihood bootstrapping (Figure 3) and Bayesian methods (not shown) yielded trees with largely unresolved among-population relationships, but again with the Palawan population well differentiated from the others.

IMa analysis yielded good mixing among successive MCMC chains (minimum swap rate $>35 \%$ ), and convergence in results was observed among different IMa runs. 


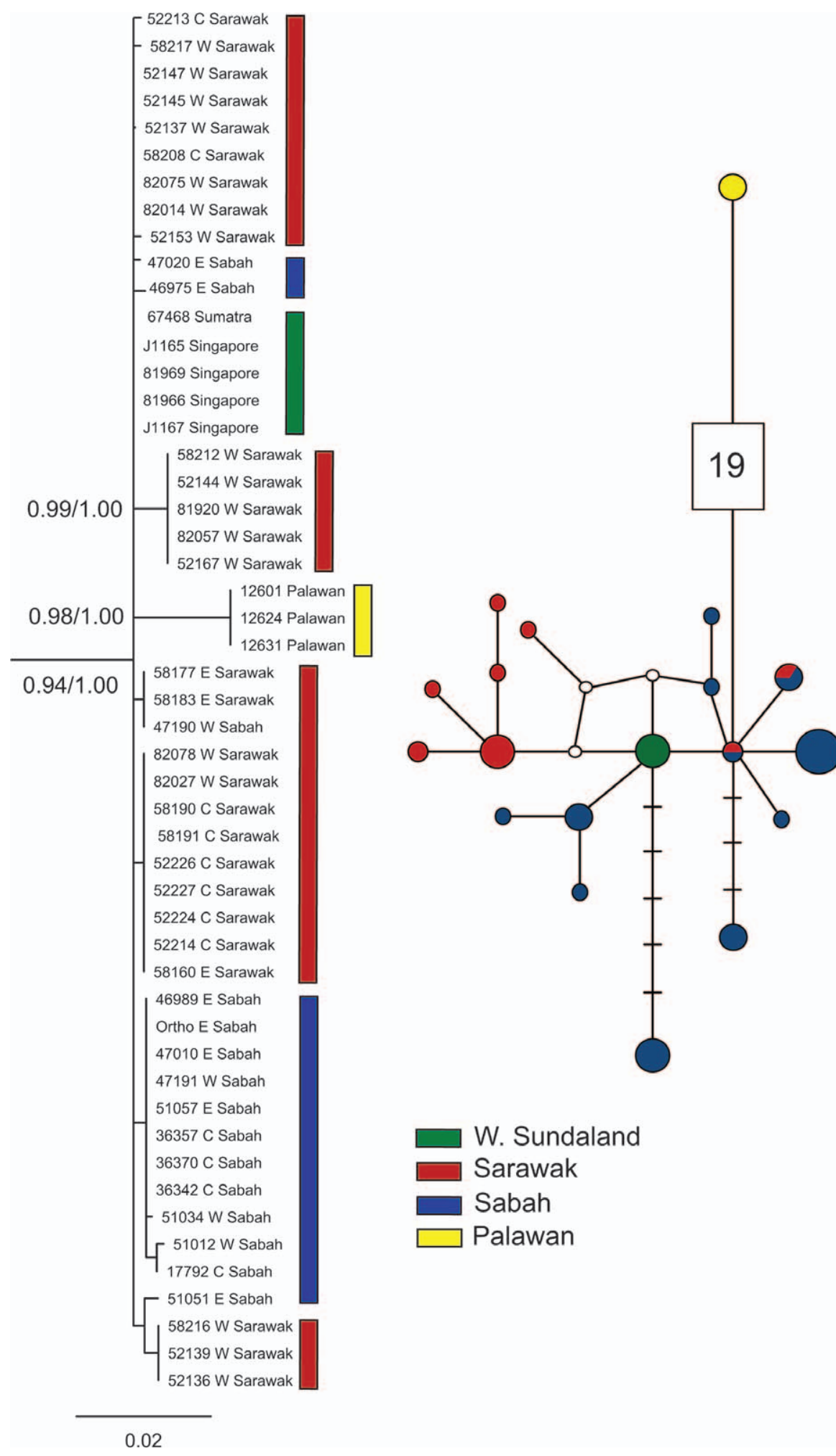

FIGURE 3. (Left) GARLI bootstrap consensus maximum-likelihood tree of Rufous-tailed Tailorbird population relationships from ND2 sequences. Numbers on the tree indicate bootstrap support/posterior probability of adjacent branches (numbers omitted when bootstrap support less than $70 \%$ or posterior probability less than $95 \%$ ). Outgroups are not included in this figure; they are Ashy Tailorbird and Grey-backed Tailorbird (Sheldon et al. 2012). (Right) Median-joining network of ND2 haplotypes. Cross hatches on interconnecting lines indicate number of substitutions (19 on the line to Palawan); circle size denotes number of individuals sampled. 
TABLE 3. Results of AMOVA among western Sunda, Borneo, and Palawan populations.

\begin{tabular}{lrccc}
\hline Source of variation & d.f. & $\begin{array}{c}\text { Sum } \\
\text { of squares }\end{array}$ & $\begin{array}{c}\text { Variance } \\
\text { components }\end{array}$ & $\begin{array}{c}\% \\
\text { of variation }\end{array}$ \\
\hline Among populations & 2 & 46.242 & 3.035 & 63 \\
Within populations & 47 & 85.238 & 1.814 & 37 \\
Total & 49 & 131.48 & 4.849 & 100 \\
\hline
\end{tabular}

For the longest IMa analysis (100 million generations, results reported here), different parameters were adequately sampled, with the minimum effective sample size being 311 (for time of divergence). Based on the full sixparameter IMa model (Table 4), the effective size of the BWS population $\left(1.3 \times 10^{6}\right)$ is about 7 times larger that of the Palawan population. Palawan and BWS diverged from a small ancestral population $\sim 1.2$ Mya, although the confidence interval for divergence time is very large. Nested IMa models (Table 5) that assume the BWS population is the same size as Palawan's or the ancestral population (model numbers $6,9,14,15$ ) are significantly worse than their respective null models, which do not assume so. Gene flow in either direction was low (range: 0-0.0003 migrants per 1,000 generations per gene copy), and the relative magnitude of directionality is not distinguishable because of the large confidence intervals. However, nested models assuming no post-divergence gene flow (model numbers 4, 8, 10,13,16) are significantly worse than their respective null models, suggesting that there has been a small amount of gene flow between BWS and Palawan after the initial population divergence. In addition, the 2 nested models with unidirectional gene flow $(2,3)$ also cannot be rejected. Thus, the evidence is equivocal regarding which direction has the higher gene flow rate.

\section{DISCUSSION}

\section{Biogeographic Patterns}

Our morphological comparisons support traditional taxonomic opinion that Rufous-tailed Tailorbirds of Palawan "do not differ appreciably" from those of Borneo (Peters 1939:110, Parkes 1960). However, our multigene coalescent analysis indicates that the populations on Borneo and
Palawan have been largely independent of one another for $\sim 1.2 \mathrm{Ma}$ and have experienced only a small amount of gene flow since then. Even when the sea level dropped by its greatest extent-about $125 \mathrm{~m}$ during the last glacial maximum $(\sim 20,000$ years ago $)$-and the channel between Palawan and the rest of Sundaland was at its narrowest, gene flow was low. This rather decisive break contrasts strongly with the situation in western Sundaland, where the Sumatran, Malayan, and Bornean populations have extensively interbred, presumably during a series of glacial events, including the last glacial maximum (Lim et al. 2011). We may also assume, with some confidence, that the Natuna Islands' population of Rufous-tailed Tailorbird interbred with Bornean and other western populations during the late Quaternary because of the Natunas' intervening position (Figure 1) and the likely paleodistributions of appropriate coastal habitats (Voris 2000, Cannon et al. 2009, Slik et al. 2011). The situation for the Rufous-tailed Tailorbird populations of Cagayan Sulu and the Sulu Archipelago east of Borneo, however, remains unclear, as we have not compared (the rare) specimens from these islands and are uncertain about the extent and timing of the islands' connections to Borneo or (in the case of Cagayan Sulu) to Palawan.

The precise scenario of division between Bornean and Palawan populations of Rufous-tailed Tailorbird is unknown. As a lineage, the Rufous-tailed Tailorbird has been extant for $\sim 5-10 \mathrm{Ma}$, and there is evidence that it may be the sister group of the main clade of Philippine tailorbirds (Sheldon et al. 2012). Thus, it may have reached Palawan millions of years ago and colonized Borneo $\sim 1.2 \mathrm{Ma}$, or it may have dispersed to Palawan from Borneo for the first time $1.2 \mathrm{Ma}$, or it may have moved back and forth freely between the 2 islands until $\sim 1.2 \mathrm{Ma}$.

One million years of almost complete isolation of Palawan's Rufous-tailed Tailorbird population has not been adequate to cause it to diverge morphologically to any great extent from its Sundaic sisters. This is true even though the ecological situation for tailorbirds on Palawan is different than on Borneo and in western Sundaland. On Palawan, Rufous-tailed Tailorbird is the only species of Orthotomus, but in the rest of Sundaland at least 2 other Orthotomus species occur in sympatry with the Rufoustailed Tailorbird. Assuming competition among tailorbirds

TABLE 4. Peak estimates and their $95 \%$ confidence intervals for current and ancestral population sizes $\left(N_{\mathrm{e}}\right)$, divergence time, and gene flow (with time moving forward, not in the coalescent) from Sundaland (S) to Palawan (P) and from Palawan to Sundaland based on the full IMa model.

\begin{tabular}{lllllll}
\hline & Palawan $N_{\mathrm{e}}$ & Sundaland $N_{\mathrm{e}}$ & Ancestral $N_{\mathrm{e}}$ & Time (years) & Gene Flow $\mathrm{S} \rightarrow \mathrm{P}^{*}$ & Gene Flow $\mathrm{P} \rightarrow \mathrm{S}^{*}$ \\
\hline Peak estimate & $1.68 \mathrm{E}+05$ & $1.28 \mathrm{E}+06$ & $7.50 \mathrm{E}+04$ & $1.19 \mathrm{E}+06$ & $0.00 \mathrm{E}+00$ & $3.02 \mathrm{E}-04$ \\
$95 \%$ confidence interval & $6.56 \mathrm{E}+04$ to & $8.54 \mathrm{E}+05$ to & $5.15 \mathrm{E}+03$ to & $3.65 \mathrm{E}+05$ to & 0.00 to & $5.03 \mathrm{E}-05$ to \\
& $7.74 \mathrm{E}+05$ & $2.11 \mathrm{E}+06$ & $3.74 \mathrm{E}+05$ & $2.36 \mathrm{E}+06$ & $8.59 \mathrm{E}-03$ & $2.16 \mathrm{E}-03$ \\
\hline
\end{tabular}

*Average number of migrants per 1,000 generations per gene copy. 
TABLE 5. Marginal likelihood and peak estimates of the full and various reduced (nested) IMa models. Likelihood ratio test (LLR) statistic, models being compared, and significance of the statistic with and without Bonferroni correction (BC) are also shown. Population 1 = Palawan; population $2=$ Borneo and western Sundaland. Because IMa analyzes data in the coalescent, $m_{1}$ indicates gene flow going from population 2 into population 1 when time is moving forward.

\begin{tabular}{|c|c|c|c|c|c|c|c|c|c|c|c|c|c|c|}
\hline Model no. & Model $^{1}$ & $\log (P)$ & $t$ & $\Theta_{1}(\mathrm{~A})$ & $\Theta_{2}(\mathrm{~B})$ & $\Theta_{\mathrm{A}}(\mathrm{C})$ & $m_{1}(\mathrm{D})$ & $m_{2}(\mathrm{E})$ & $D f^{1}$ & $\begin{array}{c}\text { vs } \\
\text { Model }\end{array}$ & 2LLR & $P$ & $\begin{array}{c}\text { Significant } \\
\text { without } \mathrm{BC}^{2} \text { ? }\end{array}$ & $\begin{array}{l}\text { Significant } \\
\text { with } B C^{2} \text { ? }\end{array}$ \\
\hline FULL & $A B C D E$ & -0.5775 & 1.0601 & 0.234 & 3.399 & $<0.001$ & 3.948 & 0.529 & & & & & & \\
\hline 1 & $A B C D D$ & -1.792 & 1.479 & 0.407 & 2.923 & 0.001 & 1.075 & 1.075 & 1 & Full & 2.429 & 0.119 & No & No \\
\hline 2 & ABCDO & -2.471 & 0.939 & 0.341 & 3.000 & 0.005 & 5.993 & 0.000 & $1^{*}$ & Full & 3.786 & 0.026 & Yes & No \\
\hline 3 & $A B C O D$ & -1.451 & 0.827 & 1.096 & 2.997 & 0.002 & 0.000 & 1.893 & $1^{*}$ & Full & 1.747 & 0.093 & No & No \\
\hline 4 & $\mathrm{ABCO0}$ & -7.333 & 0.150 & 0.843 & 3.000 & 1.739 & 0.000 & 0.000 & $2^{*}$ & ABCDD & 11.081 & 0.000 & Yes & Yes \\
\hline 5 & AACDE & -3.415 & 0.886 & 2.022 & 2.022 & 0.007 & 0.000 & 3.223 & 1 & Full & 5.675 & 0.017 & Yes & No \\
\hline 6 & AAADE & -9.160 & 1.846 & 2.070 & 2.070 & 2.070 & 0.000 & 1.988 & 2 & Full & 17.165 & 0.000 & Yes & Yes \\
\hline 7 & AACDD & -5.399 & 1.320 & 2.660 & 2.660 & 0.007 & 1.149 & 1.149 & 2 & Full & 9.643 & 0.008 & Yes & No \\
\hline 8 & AACOO & -14.523 & 0.163 & 3.000 & 3.000 & 1.776 & 0.000 & 0.000 & $3^{*}$ & AACDD & 18.249 & 0.000 & Yes & Yes \\
\hline 9 & AAADD & -10.801 & 0.640 & 2.105 & 2.105 & 2.105 & 0.878 & 0.878 & 3 & Full & 20.447 & 0.000 & Yes & Yes \\
\hline 10 & AAA00 & -22.790 & 0.170 & 2.624 & 2.624 & 2.624 & 0.000 & 0.000 & $4^{*}$ & AAADD & 23.978 & 0.000 & Yes & Yes \\
\hline 11 & ABADE & -2.801 & 0.820 & 0.469 & 3.000 & 0.469 & 2.052 & 0.562 & 1 & Full & 4.447 & 0.035 & Yes & No \\
\hline 12 & ABADD & -3.047 & 0.793 & 0.614 & 3.000 & 0.614 & 0.843 & 0.843 & 2 & Full & 4.940 & 0.085 & No & No \\
\hline 13 & ABA00 & -9.868 & 0.158 & 1.656 & 3.000 & 1.656 & 0.000 & 0.000 & $3^{*}$ & ABADD & 13.642 & 0.000 & Yes & Yes \\
\hline 14 & ABBDE & -5.021 & 2.755 & 0.658 & 3.000 & 3.000 & 0.000 & 1.804 & 1 & Full & 8.887 & 0.003 & Yes & Yes \\
\hline 15 & ABBDD & -7.936 & 1.668 & 0.517 & 2.799 & 2.799 & 1.261 & 1.261 & 2 & Full & 14.717 & 0.001 & Yes & Yes \\
\hline 16 & ABB00 & -17.096 & 0.169 & 0.922 & 2.708 & 2.708 & 0.000 & 0.000 & $3^{*}$ & ABBDD & 18.319 & 0.000 & Yes & Yes \\
\hline
\end{tabular}

${ }^{1}$ Models are based on 5 parameters: $(A)$ size of population $1\left(\Theta_{1}\right) ;(B)$ size of population $2\left(\Theta_{2}\right) ;(C)$ size of the ancestral population $\left(\Theta_{A}\right) ;(D)$ gene flow going from population 2 (Borneo and western Sundaland) into population 1 (Palawan); (E) gene flow going from population 1 (Palawan) into population 2 (Borneo and western Sundaland). For models with at least one variable set to 0, the test chi-squared distribution is a mixture. See Hey and Nielsen (2007) for further details.

${ }^{2} \mathrm{BC}=$ Bonferroni correction. A lack of significance suggests that the tested model is no worse than the fuller model.

(Mitra and Sheldon 1993, Soh 2001, Mahood et al. 2013), the Rufous-tailed Tailorbird of Palawan has enjoyed ecological release and would be expected to differ from other populations, especially in size (Clegg and Owens 2002, Scott et al. 2003). The Palawan population may have diverged in behavior and song, but we have not investigated these characters.

The genetic distance between the Rufous-tailed Tailorbird populations of Borneo and Palawan-1.7\% in this study and $1.9 \%$ in previous studies-falls somewhat in the middle of the 2 divergence classes evident between Palawan and Bornean sister taxa in Table 1 (i.e. substantial divergence versus little divergence). The 2 tailorbird populations are more distinct genetically than those of kingfishers (Ceyx erithaca and Alcedo meninting) and Black-headed Bulbul (Pycnonotus atriceps), but much less than the other sister pairs. This difference may be attributed to the tailorbird's reduced dispersal capabilities relative to the kingfishers and bulbul (Burney and Brumfield 2009). Birds in both these groups range widely in coastal areas in search of food and have wings with relatively high aspect ratios compared to the short, rounded wings of tailorbirds. On the other hand, Rufoustailed Tailorbird would be expected to disperse across salt water more readily than "typical" Sunda forest species because of its regular occurrence in mangroves and other coastal habitats (Van Marle and Voous 1988, Sheldon et al.
2001, Wells 2007), which likely predominated between Greater Borneo and Palawan during glacial events. Even so, it is not easy to explain why the weak-flying tailorbird should have a smaller pairwise population divergence value than some of the highly vagile, nectarivorous/frugivorous, coastal habitat generalist species in Table 1. We would expect, for example, that the mangrove-dwelling whistlers and wide-ranging spiderhunters and secondary forest bulbuls (e.g., Pycnonotus simplex/cinereifrons) would be able to disperse more readily than tailorbirds between Borneo and Palawan during times of low sea level. Birdcommunity "relaxation" factors (Diamond 1972), such as competition and extinction, clearly have played a role in determining the composition of the Palawan avifauna.

\section{Taxonomy}

A relatively large proportion of Philippine forest birds are classified as members of widespread Southeast Asian species when they are better treated as endemic Philippine species (Peterson 2006, Lohman et al. 2010). This underestimation of Philippine species endemicity is largely a historical artifact, a hangover from taxonomic and biogeographic thinking of the mid-twentieth century. Although ornithologists have long recognized the distinctiveness of many Philippine forest-bird populations, they have purposely treated them as subspecies, not full species. This occurred because, in the years following World War 
II, when taxonomic revision of birds was booming, the study of Southeast Asian bird relationships was dominated by ornithologists at American museums, including Herbert G. Deignan, Jean Delacour, Ernst Mayr, Kenneth C. Parkes, Austin L. Rand, and S. Dillon Ripley, and all of these men were heavily influenced by the polytypic species approach of Mayr $(1942,1963)$. It was quite natural for them to treat populations of similar-looking congeners that replace one another geographically as subspecies of widespread species. This tendency was exacerbated by the prevailing view of Philippine biogeography at the time, i.e. that Philippine populations were the result of late Pleistocene or Holocene expansions of widespread continental species. The presumed young age of Philippine taxa was all the more reason to join them as polytypic members of widespread species. Nowadays, however, we know that many Philippine forest populations are older than previously believed, and we have different and more precise standards of species description as a result of the promulgation of alternative species concepts that emphasize smaller groupings (McKitrick and Zink 1988), the development of more objective methods of morphological assessment (Rheindt and Eaton 2009, Tobias et al. 2010), and the widespread use of molecular tools that allow measurement of divergence among taxa.

As a result of these advances, we are now in a position to treat the taxonomy of Philippine populations more objectively. This ability is enhanced by the recent suggestion of Gill (2014) that physically separated, moderately divergent populations be treated as distinct species until compelling evidence of free interbreeding is produced, upon which the populations may be merged. In the Rufous-tailed Tailorbird, we have an almost perfect illustration of such "compelling evidence," not only for interbreeding, but lack of interbreeding. Our genetic comparisons allow us to identify with confidence those populations that are interbreeding and those that are not. In this case, the Bornean and western Sunda populations are genetically intermixed and barely (if at all) differentiated morphologically. We can essentially prove these populations interbred during the last glacial maximum and were probably in contact until 10,000 years ago (Lim et al. 2011). Thus, they can be considered without question members of the same species. The Palawan population, however, is genetically distinct. Palawan has not been regularly attached to the rest of Sundaland by glacioeustatic land or habitat bridges, and its population of tailorbirds has rarely interbred with the Bornean population. Thus, the Palawan population appears to be on its own evolutionary trajectory. However, it has not yet diverged morphologically, and we know of no non-DNA characteristics that distinguish it from the Bornean population, so there is no reason to call it a different species at this point. If diagnosable differences in song or behavior are discovered for the Palawan population, it should then be named a different species.

Our personal preference is not to change the classification of Rufous-tailed Tailorbird populations, i.e. maintain the subspecies as they are. Although the western Sunda and Borneo populations do not appear to us to differ from one another morphologically, fresh specimens from Sumatra and the Malay Peninsula might exhibit plumage differences from Bornean birds. Naming the Palawan population as a distinct taxon, e.g., in recognition of its genetic distinctiveness or in the case of new character discovery, will have to wait until genetic comparisons are made between it and the Cagayan Sulu population, because the Palawan population is subsumed under the name given the Cagayan Sulu population (Orthotomus sericeus nuntius) by Bangs (1922).

\section{ACKNOWLEDGMENTS}

For permission to undertake research in Malaysia we thank the Prime Minister's Department; the Chief Ministers' Departments of Sabah and Sarawak; Sabah Parks, Wildlife, and Forestry Departments; and Sarawak Forestry Department, Forestry Corporation, and Biodiversity Institute. We also thank the staff of Sabah Parks (Dr. Jamili Nais, Dr. Maklarin Lakim, Alim Biun, Paul Yambun, and Benedict Butit), Sabah Museum (Jaffit Majuakim, Albert Lo, Freddie Julus, Patrick Francis, Mathius Angkaus), Sabah Wildlife Department (Augustine Tuuga, Peter Malim, Anna Wong), and UNIMAS (Isa Said, Mohamad Fizl Sidq Ramji, Mohamad Jalani Mortada, and numerous graduate students). For permission to work in Palawan, we thank the Philippine Department of Environment and Natural Resources and the Palawan Council for Sustainable Development. For use of morphological and genetic specimens, we thank the Academy of Natural Sciences of Drexel University, American Museum of Natural History, Delaware Museum of Natural History, Field Museum, Louisiana State University Museum of Natural Science, National Museum of Natural History (USA), Natural History Museum (UK), University of Kansas Museum of Natural History, and Western Foundation of Vertebrate Zoology. This work was supported financially by NSF DEB-0228688 and DEB-1241059 to F.H.S., FRGS/06(03)/647/2007(12) to M.A.R., and by the Coypu Foundation, Louisiana State University, and Universiti Malaysia Sarawak.

\section{LITERATURE CITED}

Backström, N., S. Fagerberg, and H. Ellegren (2008a). Genomics of natural bird populations: A gene-based set of reference markers evenly spread across the avian genome. Molecular Ecology 17:964-980.

Backström, N., N. Karaiskou, E. H. Leder, L. Gustafsson, C. R. Primmer, A. Qvarnström, and H. Ellegren (2008b). A genebased genetic linkage map of the collared flycatcher (Ficedula albicollis) reveals extensive synteny and gene-order conser- 
vation during 100 million years of avian evolution. Genetics 179:1479-1495.

Bandelt, H.-J., P. Forster, and A. Röhl (1999). Median-joining networks for inferring intraspecific phylogenies. Molecular Biology and Evolution 16:37-48.

Bangs, O. (1922). Notes on Philippine birds collected by Governor W. Cameron Forbes. Bulletin of the Museum of Comparative Zoology 65:77-84.

Bintanja, R., S. W. van de Wal, and J. Oelemans (2005). Modelled atmospheric temperatures and global sea levels of the past million years. Nature 437:125-128.

Blackburn, D. C., D. P. Bickford, A. C. Diesmos, D. T. Iskandar, and R. M. Brown (2010). An ancient origin for the enigmatic flatheaded frogs (Bombinatoridae: Barbourula) from the islands of Southeast Asia. PLoS ONE 5:e12090.

Borge, T., M. T. Webster, G. Andersson, and G.-P. Saetre (2005). Contrasting patterns of polymorphism and divergence on the $\mathrm{Z}$ chromosome and autosomes in two Ficedula flycatcher species. Genetics 171:1861-1873.

Brandon-Jones, D. (1998). Pre-glacial Bornean primate impoverishment and Wallace's line. In Biogeography and Geological Evolution of SE Asia (R. Hall and J. D. Holloway, Editors). Backhuys Publishers, Leiden, The Netherlands. pp. 393-403.

Burney, C. W., and R. T. Brumfield (2009). Ecology predicts levels of genetic differentiation in Neotropical birds. The American Naturalist 174:358-368.

Cannon, C. H., R. J. Morley, and A. B. G. Bush (2009). The current refugial rainforests of Sundaland are unrepresentative of their biogeographic past and highly vulnerable to disturbance. Proceedings of the National Academy of Sciences USA 106: 11188-11193.

Chasen, F. N., and C. B. Kloss (1931). Two new Malaysian subspecies of birds. Novitates Zoologicae 36:279.

Clegg, S. M., and P. Owens (2002). The 'island rule' in birds: Medium body size and its ecological explanation. Proceedings of the Royal Society of London, Series B 269:1359-1365.

Darlington, P. J. (1957). Zoogeography: The Geographical Distribution of Animals. Wiley, New York, NY, USA.

Delacour, J., and E. Mayr (1946). Birds of the Philippines. Macmillan, New York, NY, USA.

Diamond, J. M. (1972). Biogeographic kinetics: Estimation of relaxation times for avifaunas of Southwest Pacific islands. Proceedings of the National Academy of Sciences USA 69: 3199-3203.

Diamond, J. M., and M. E. Gilpin (1983). Biogeographic umbilici and the origin of the Philippine avifauna. Oikos 41:307-321.

Dickerson, R. E., E. D. Merrill, R. C. McGregor, W. Schultze, E. H. Taylor, and A. W. Herre (1928). Distribution of Life in the Philippines. Bureau of Printing, Manila, Philippines.

Dickinson, E. C. (1991). Biogeography of Philippine birds. In The Birds of the Philippines: An Annotated Check-list. BOU Checklist Series No. 12 (E. C. Dickinson, R. S. Kennedy, and K. C. Parkes, Editors). British Ornithologists' Union, Tring, Herts, UK. pp. 24-46.

Dickinson, E. C., R. S. Kennedy, and K. C. Parkes (Editors) (1991). The Birds of the Philippines. British Ornithologists' Union, Tring, Herts, UK.

Durkee, E. F. (1993). Oil, geology and changing concepts in the Southwest Philippines (Palawan and the Sulu Sea). Bulletin of the Geological Society of Malaysia 33:241-262.
Esselstyn, J. A., C. H. Oliveros, R. G. Moyle, A. T. Peterson, J. A. McGuire, and R. M. Brown (2010). Integrating phylogenetic and taxonomic evidence illuminates complex biogeographic patterns along Huxley's modification of Wallace's Line. Journal of Biogeography 37:2054-2066.

Excoffier, L., and H. E. L. Lischer (2010). Arlequin suite ver 3.5: A new series of programs to perform population genetics analyses under Linux and Windows. Molecular Ecology Resources 10:564-567.

Gamauf, A., and E. Haring (2004). Molecular phylogeny and biogeography of honey-buzzards (genera Pernis and Henicopernis). Journal of Zoological Systematics and Evolutionary Research 42:145-153.

Gathorne-Hardy, F. J., Syaukani, R. G. Davies, P. Eggleton, and D. T. Jones (2002). Quaternary rainforest refugia in south-east Asia: Using termites (Isoptera) as indicators. Biological Journal of the Linnean Society 75:453-466.

Gill, F. B. (2014). Species taxonomy of birds: Which null hypothesis? The Auk 131:150-161.

Gill, F. B., and D. Donsker (Editors) (2014). IOC World Bird List. Version 4.2. doi:10.14344/IOC.ML.4.2

Gorog, A. J., M. H. Sinaga, and M. D. Engstrom (2004). Vicariance or dispersal? Historical biogeography of three Sunda shelf murine rodents (Maxomys surifer, Leopoldamys sabanus and Maxomys whiteheadi). Biological Journal of the Linnean Society 81:91-109.

Hall, R. (1998). The plate tectonics of Cenozoic SE Asia and the distribution of land and sea. In Biogeography and Geological Evolution of SE Asia (R. Hall and J. D. Holloway, Editors). Backhuys Publishers, Leiden, The Netherlands. pp. 99-131.

Hall, R. (2002). Cenozoic geological and plate tectonic evolution of SE Asia and the SW Pacific: Computer-based reconstructions and animations. Journal of Asian Earth Sciences 20:353434.

Hall, R. (2009). Southeast Asia's changing palaeogeography. Blumea: Biodiversity, Evolution and Biogeography of Plants $54: 1-3$

Heaney, L. R. (1985). Zoogeographic evidence for middle and late Pleistocene land bridges to the Philippine Islands. Modern Quaternary Research in Southeast Asia 9:127-144.

Heaney, L. R. (1986). Biogeography of mammals in SE Asia: Estimates of rates of colonization, extinction and speciation. Biological Journal of the Linnean Society 28:127-165.

Hey, J., and R. Nielsen (2004). Multilocus methods for estimating population sizes, migration rates and divergence time, with applications to the divergence of Drosophila pseudooscura and D. persimilis. Genetics 167:747-760.

Hey, J., and R. Nielsen (2007). Integration within the Felsenstein equation for improved Markov chain Monte Carlo methods in population genetics. Proceedings of the National Academy of Sciences USA 104:2785-2790.

Inger, R. F. (1954). Systematics and zoogeography of Philippine Amphibia. Fieldiana 33:183-531.

Irestedt, M., P. H. Fabre, H. Batalha, K. A. Jønsson, C. S. Roselaar, G. Sangster, and P. G. P. Ericson (2013). The spatio-temporal colonization and diversification across the Indo-Pacific by a 'great speciator' (Aves, Erythropitta erythrogaster). Proceedings of the Royal Society of London, Series B 280:20130309.

Jones, A. W., and R. S. Kennedy (2008). Evolution in a tropical archipelago: Comparative phylogeography of Philippine fauna and flora reveals complex patterns of colonization 
and diversification. Biological Journal of the Linnean Society 95:620-639.

Kimball, R. T., E. L. Braun, F. K. Barker, R. C. K. Bowie, M. J. Braun, J. L. Chojnowski, S. Hackett, K., L. Han, J. Harshman, V. HeimerTorres, W. Holznagel, et al. (2009). A well-tested set of primers to amplify regions spread across the avian genome. Molecular Phylogenetics and Evolution 50:654-660.

Lim, H. C., M. A. Rahman, S. L. H. Lim, R. G. Moyle, and F. H. Sheldon (2011). Revisiting Wallace's haunt: Coalescent simulations and comparative niche modeling reveal historical mechanisms that promoted avian population divergence in the Malay Archipelago. Evolution 65:321-334.

Lim, H. C., and F. H. Sheldon (2011). Multilocus analysis of the evolutionary dynamics of rainforest bird populations in Southeast Asia. Molecular Ecology 20:3414-3438.

Lim, H. C., F. Zou, S. S. Taylor, B. D. Marks, R. G. Moyle, G. Voelker, and F. H. Sheldon (2010). Phylogeny of magpie-robins and shamas (Aves: Turdidae: Copsychus and Trichixos): Implications for island biogeography in Southeast Asia. Journal of Biogeography 37:1894-1906.

Lohman, D. J., K. K. Ingram, D. M. Prawiradilaga, K. Winker, F. H. Sheldon, R. G. Moyle, P. K. L. Ng, P. S. Ong, L. K. Wang, T. M. Braile, D. Astutic, and R. Meier (2010). Cryptic genetic diversity in "widespread" Southeast Asian bird species suggests that Philippine avian endemism is gravely underestimated. Biological Conservation 143:1885-1890.

Madge, S. C. (2006). Family Cisticolidae (Cisticolas and allies) [Orthotomus accounts]. In Handbook of the Birds of the World, Volume 11 (J. del Hoyo, A. B. Elliott, and D. Christie, Editors). Lynx Edicions, Barcelona, Spain. pp. 423-427.

Mahood, S. P., A. J. I. John, J. C. Eames, C. H. Oliveros, R. G. Moyle, H. Chamnan, C. M. Poole, H. Nielsen, and F. H. Sheldon (2013). A new species of lowland tailorbird (Passeriformes: Cisticolidae: Orthotomus) from the Mekong floodplain of Cambodia. Forktail 29:1-14.

Mayr, E. (1942). Systematics and the Origin of Species. Columbia University Press, New York, NY, USA.

Mayr, E. (1963). Animal Species and Evolution. Belknap Press, Cambridge, MA, USA.

McKitrick, M. C., and R. M. Zink (1988). Species concepts in ornithology. The Condor 90:1-14.

Meijaard, E., and A. P. M. van der Zon (2003). Mammals of southeast Asian islands and their Late Pleistocene environments. Journal of Biogeography 30:1245-1257.

Mitra, S., and F. H. Sheldon (1993). Use of an exotic tree plantation by Bornean lowland forest birds. The Auk 110: 529-540.

Moyle, R. G., C. E. Filardi, C. E. Smith, and J. Diamond (2009). Explosive Pleistocene diversification and hemispheric expansion of a "great speciator." Proceedings of the National Academy of Sciences USA 106:1863-1868.

Moyle, R. G., J. Fuchs, E. Pasquet, and B. D. Marks (2007). Feeding behavior, toe count, and the phylogenetic relationships among alcedinine kingfishers (Alcedininae). Journal of Avian Biology 38:317-326.

Nguembock, B., J. Fjeldsa, A. Tillier, and E. Pasquet (2007). A phylogeny for the Cisticolidae (Aves : Passeriformes) based on nuclear and mitochondrial DNA sequence data, and a reinterpretation of an unique nest-building specialization. Molecular Phylogenetics and Evolution 42:272-286.
Oberholser, H. C. (1932). The birds of the Natuna Islands. United States National Museum Bulletin 159:1-137.

Oliveros, C. H., and R. G. Moyle (2010). Origin and diversification of Philippine bulbuls. Molecular Phylogenetics and Evolution 54:822-832.

Oliveros, C. H., S. Reddy, and R. G. Moyle (2012). The phylogenetic position of some Philippine "babblers" spans the muscicapoid and sylvioid bird radiations. Molecular Phylogenetics and Evolution 65:799-804.

Parkes, K. C. (1960). Notes on some Philippine tailor-birds. Bulletin of the British Ornithological Club 80:76-78.

Peters, J. L. (1939). Collections from the Philippine Islands. Birds. Bulletin of the Museum of Comparative Zoology 86:74-128.

Peterson, A. T. (2006). Taxonomy is important in conservation: A preliminary reassessment of Philippine species-level bird taxonomy. Bird Conservation International 16:155-173.

Phillipps, Q., and K. Phillipps (2014). Phillipps' Field Guide to the Birds of Borneo, 3rd edition. John Beaufoy, Oxford, England.

Posada, D. (2008). jModelTest: Phylogenetic model averaging. Molecular Biology and Evolution 25:1253-1256.

Primmer, C. R., T. Borge, J. Lindell, and G. P. Saetre (2002). Singlenucleotide polymorphism characterization in species with limited available sequence information: High nucleotide diversity revealed in the avian genome. Molecular Ecology 11:603-612.

R Development Core Team (2008). R: A language and environment for statistical computing. $R$ Foundation for Statistical Computing, Vienna, Austria.

Rahman, M. A., D. F. A. Gawin, and C. Moritz (2010). Patterns of genetic variation of the little spiderhunter (Arachnothera longirostra) in Southeast Asia. Raffles Bulletin of Zoology 58: 381-390.

Rheindt, F. E., and J. A. Eaton (2009). Species limits in Pteruthius (Aves: Corvida) shrike-babblers: A comparison between the Biological and Phylogenetic Species Concepts. Zootaxa 2301: 29-54.

Rohling, E. J., M. Fenton, F. J. Jorissen, G. Bertrand, G. Ganssen, and J. P. Caulet (1998). Magnitude of sea level lowstands of the last 500,000 years. Nature 394:162-165.

Ronquist, F., M. Teslenko, P. van der Mark, D. L. Ayres, A. Darling, S. Hohna, B. Larget, L. Liu, M. A., Suchard, and J. P. Huelsenbeck (2012). MrBayes 3.2: Efficient Bayesian phylogenetic inference and model choice across a large model space. Systematic Biology 61:539-542.

Sathiamurthy, E., and H. K. Voris (2006). Maps of Holocene sea level transgressions and submerged lakes on the Sunda shelf. The Natural History Journal of Chulalongkorn University S2:143.

Scott, S. N., S. M. Clegg, S. P. Blomberg, J. Kikkawa, and I. P. F. Owens (2003). Morphological shifts in island-dwelling birds: The roles of generalist foraging and niche expansion. Evolution 57:2147-2156.

Seutin, G., B. N. White, and P. T. Boag (1991). Preservation of avian blood and tissue samples for DNA analysis. Canadian Journal of Zoology 68:82-90.

Sheldon, F. H., D. J. Lohman, H. C. Lim, F. Zou, S. M. Goodman, D. M. Prawiradilaga, K. Winker, T., M. Braile, and R. G. Moyle (2009). Phylogeography of the magpie-robin species complex (Aves: Turdidae: Copsychus) reveals a Philippine species, an interesting isolating barrier, and unusual dispersal 
patterns in the Indian Ocean and Southeast Asia. Journal of Biogeography 36:1070-1083.

Sheldon, F. H., R. G. Moyle, and J. Kennard (2001). Ornithology of Sabah: History, gazetteer, annotated checklist, and bibliography. Ornithological Monographs 52:1-285.

Sheldon, F. H., C. H. Oliveros, S. S. Taylor, B. McKay, H. C. Lim, M. A. Rahman, H. Mays, and R. G. Moyle (2012). Molecular phylogeny and insular biogeography of the lowland tailorbirds of Southeast Asia (Cisticolidae: Orthotomus). Molecular Phylogenetics and Evolution 65:54-63.

Siler, C. D., J. R. Oaks, L. J. Welton, C. W. Linkem, J. C. Swab, A. C. Diesmos, and R. M. Brown (2012). Did geckos ride the Palawan raft to the Philippines? Journal of Biogeography 39: 1217-1234.

Slik, J. W. F., S.-I. Aiba, M. Bastian, F. Q. Brearley, C. H. Cannon, K. A. O. Eichhorn, G. Fredriksson, K. Kartawinata, Y. Laumonier, A. Mansor, A. Marjokorpi, et al. (2011). Soils on exposed Sunda Shelf shaped biogeographic patterns in the equatorial forests of Southeast Asia. Proceedings of the National Academy of Sciences USA 108:12343-12347.

Smythies, B. E. (1999). The Birds of Borneo, 4th edition. Natural History Publications (Borneo), Kota Kinabalu, Malaysia.

Soh, M. C. K. (2001). Foraging behaviour of two tailorbirds in Singapore: Habitat, morphological, and temporal comparisons. Raffles Bulletin of Zoology 40:173-180.

Tobias, J. A., N. Seddon, C. N. Spottiswoode, J. D. Pilgrim, L. D. Fishpool, and N. J. Collar (2010). Quantitative criteria for species delimitation. Ibis 152:724-746.

Van Marle, J. G., and K. H. Voous (1988). The Birds of Sumatra. British Ornithologists' Union, Tring, Herts, UK.
Venables, W. N., and B. D. Ripley (2002). Modern Applied Statistics with S, 4th edition. Springer, New York, NY, USA.

Voris, H. K. (2000). Maps of Pleistocene sea levels in Southeast Asia: shorelines, river systems and time durations. Journal of Biogeography 27:1153-1167.

Wells, D. R. (2007). The Birds of the Thai-Malay Peninsula, Volume 2, Passerines. Christopher Helm, London, England.

Whitmore, T. C. (1981). Wallace's Line and Plate Tectonics. Oxford University Press, Oxford, England.

Whitmore, T. C. (1987). Biogeographic Evolution of the Malay Archipelago. Clarendon Press, Oxford, England.

Wurster, C. M., M. I. Bird, I. D. Bull, F. Creed, C. Bryant, J. A. J. Dungait, and V. Paz (2010). Forest contraction in north equatorial Southeast Asia during the Last Glacial Period. Proceedings of the National Academy of Sciences USA 107: 15508-15511.

Yumul, G. P., C. B. Dimalanta, E. J. Marquez, and K. L. Queaño (2009). Onland signatures of the Palawan microcontinental block and Philippine mobile belt collision and crustal growth process: A review. Journal of Asian Earth Sciences 34:610623.

Zamoros, L. R., and A. Matsuoka (2004). Accretion and postaccretion tectonics of the Calamian Islands, North Palawan block, Philippines. Island Arc 13:506-619.

Zwickl, D. J. (2006). Genetic algorithm approaches for the phylogenetic analysis of large biological sequence datasets under the maximum likelihood criterion. Ph.D. dissertation, University of Texas at Austin, TX, USA. 